The point here is not that the gloominess did not exist, nor that in retrospect some of it might be fading, but rather that unemployment and lack of maternity benefits, indeed the disastrous American health care system, are deproblematized at a stroke. The passage may also give some hint of a reason for the resistance to feminism which has been so widely noted in post-communist society - for, in pointing to the thwarted ambition and initiative of millions of 'people', is the author not also very close to expressing a gendered concern for the 'ghostly and fictitious' men of state socialism which Larissa Lissyutkina, for example, describes in her chapter entitled 'Soviet women at the crossroads of perestroika' (Lissyutkina/Funk and Mueller, p. 283)?

Peggy Watson

\title{
Straight Sex: The Politics of Pleasure
}

\section{Lynne Segal}

Virago: London, 1994

ISBN 185381802 X, $\mathbf{8 8 . 9 9}$

Lynne Segal's aim in this book is to challenge what she sees as current feminist orthodoxy: namely the idea that heterosexuality is the basis of men's exploitation of women, and the related notion that lesbianism is the most authentic expression of feminist politics. According to Segal, feminists have had almost nothing to say about love or desire, and, by their silence, have allowed a few very visible feminists to set the agenda. Segal paints a bleak picture of both the apparent lack of debate among feminists, and the ability of contemporary feminism to speak to the experiences of the vast majority of heterosexual women. She depicts a repressive atmosphere, the tone of which was set by campaigns against pornography, in which women feel unable to talk about sexual pleasure.

The purpose of Straight Sex is to challenge this. Segal argues that alongside confident lesbian and gay campaigns around sexuality, we need reversals of the dominant, phallic constructions of heterosexuality: 'Instead of guilt-tripping heterosexual women, feminists would do better to enlist them in the "queering" of traditional understanding of gender and sexuality' (p. xv). Straight sex, Segal asserts, may be no more affirmative of normative gender positions than gay and lesbian sex.

The book begins with Segal's own sexual and political formation in the 1960s. The story told is a familiar one; the trajectory traced is one from a time when women saw sex as liberation to one in which they sought 
liberated sex. The second chapter takes up the story at this point, outlining the disagreements between feminists about the nature of men's domination. Here Segal draws on themes developed in her other books, to argue that the preoccupation with sexual violence, rape and pornography lead to a kind of essentialism and ahistoricism in much feminist thought, and a sense of the inevitability of men's exploitation of women. In her words, 'the tendency simply to blame men . . . was soon to overtake the passion to reform them' (p. 49). Chapters 3 and 4 review the literatures of sex research and psychoanalysis respectively, and Chapter 5 examines the contribution made to feminism by queer theory and practice. The final chapters are devoted to Segal's attempt to rethink heterosexuality in such a way as to challenge dominant and oppressive constructions of it.

Like all Segal's books, Straight Sex is beautifully written. She is a meticulous researcher, but handles complex ideas so fluently that she is able to render them easily accessible without losing any of their subtlety or nuances. Her discussions of psychoanalytic theory and of Judith Butler's work will become fixtures on my undergraduate reading lists for this reason. The book is a pleasure to read and is considerably enriched by the fragments of feminist poetry which illustrate many of her discussions. Overall, then, Straight Sex deserves much more attention than I am able to give it in this short review. In the remainder I will focus on a few aspects of the book which I found disquieting.

The first thing which troubled me was the way Segal set up the argument, as a challenge to feminist orthodoxy. Perhaps I am too young, do not mix in the 'right' circles, or am not sufficiently well-read, but I simply did not recognize her portrait of feminism's dominant line on heterosexuality. The attribution of orthodoxy seemed to rest primarily upon a couple of rather old titles, which in no way reflect the dynamism and diversity of opinion of the feminism that $I$ know. The repressive atmosphere of being guilttripped and silenced by other feminists about being straight is not one which I regularly encounter. So, on the one hand, this portrayal simply did not 'ring true' for me. But perhaps more significantly, I am troubled by the very use of the idea of a feminist orthodoxy. It seems to me that to claim this is not simply to misrepresent feminism, but to play into the hands of our critics - by reinforcing their conviction that feminism is a rigid, dogmatic line to which strict adherence is required, and which silences or marginalizes dissenters from the orthodoxy.

My unease about Segal's assertion of feminist orthodoxy does not make me reject her argument. Nevertheless, there are aspects of it which I find extremely problematic. One criticism is of Segal's understanding of 
discourse. The book is influenced by a Foucauldian reading of sexuality, and a questioning of - if not scepticism about - the idea of a prediscursive body. Yet Segal is inconsistent about the status she accords to discourse, and seems unable to decide whether it is a true account or whether a layer of ideology (for example, cultural constructions of romance) has somehow intervened. More importantly, the relationship of ordinary people's discourse to broader historical constructions is not made clear.

Never is this more problematic than when the discourse at issue is women's accounts of whether they do or do not like heterosexual intercourse. Segal is scathing about Shere Hite's work, gleefully reproducing the positive statements which many of Hite's interviewees made about sex with men, in order to demonstrate Hite's bias in her reading of the result. But what Segal does not seem to recognize is that there can be many - not just one - discourses about sex, and that these are differently rewarded and sanctioned in our culture. It may be that Hite's respondents, in saying (as many of them did) that they didn't orgasm during penetrative sex but they loved it anyway, were reproducing a very traditional and socially valued discourse. It is not that this is in any sense a 'lie', or an example of 'false consciousness', but rather that sex - like most things - is constructed and lived through a multiplicity of discourses, not just one.

It seems to me that Segal is more ambivalent than she acknowledges about how much women enjoy heterosexual sex. The picture she presents is largely a very optimistic, up-beat one - there are many women getting an awful lot of pleasure from having sex with men, and they should damn well not have to apologize for it, she seems to be saying. Fine. But occasionally cracks appear in this argument, as when she acknowledges 'many women's disappointment with sex' (p. 241), or what a letdown the experience of heterosexual intercourse is for many young women. Segal rightly chastizes some researchers for letting their own assumptions inhibit their ability to recognize the very real pleasures which young women are obtaining from straight sex, but I cannot feel happy about the way she treats women's claims to gain pleasure (sometimes solely) from their partner's pleasure as unproblematic. Voyeuristic desire is fine, but if that's all you have and you want more. ...

Finally, I want to turn to Segal's main argument, namely her belief in the transgressive potential of heterosexual sex. For Segal, sexual relations between men and women threaten, rather than stabilize, gender polarity. Despite being the central argument of the book, the justifications for this claim are rather vague, but they have to do with the loss of control and 
the vulnerability which Segal says occur during sex: "[S]ex places "manhood" in jeopardy, with its masculine ideal of autonomous selfhood threatened by the self-abnegation, the self-obliteration, that sexual desire engenders' (p. 254). This is where I part company decisively with Segal. It is not that I think that this never happens, but what I object to is the way Segal suddenly projects one, unitary meaning on to sex - sex is about loss of control, it is about blurring the boundaries of the self when she has argued throughout that this cannot be sustained. Sex may have this meaning for some people at some time, but Segal cannot pronounce that this is what sexual desire is - as if it had some unproblematic essence. I am also uncomfortable with the terms she uses: these notions of transcendence are far too mystical for my liking, and they seem to idealize sexual relations. Her accounts of desire and of sex seem, by the end of the book, to have taken on an almost free-floating quality - abstracted from the social context of power relations in which they exist.

Rosalind Gill

\section{Rethinking Sexual Harassment}

\section{Edited by Clare Brant and Yun Lee Too}

Pluto Press: London, 1994

ISBN 074530838 4, f14.95 Pbk, ISBN 074530837 6, f45.00 Hbk

This book 'aims to raise consciousness about the discourse of sexual harassment and the adequacy of practice based on this language' (p. 2). It has, in this sense, a simple aim, informed by the view that the way in which discourses of sexual harassment are framed makes an important difference politically. However, that is the only overarching narrative this book provides, because it is about using detail and local analysis: 'the contributors ... show how simplified narratives and explanations of harassment disguise complexity for particular social reasons' (p. 2). The contributors represent a wide range of disciplinary perspectives, noticeably more humanities- than social science-based (history, art, cultural studies, law, women's studies, classics, anthropology and English), but they are all working in academic institutions except one, Ros Hunt, who is a priest.

These authors largely succeed in revealing complexity through working with situated examples: legal and para-legal discourses, the colonial shaping of 'Eve-teasing' in India, British men and women's systematically 